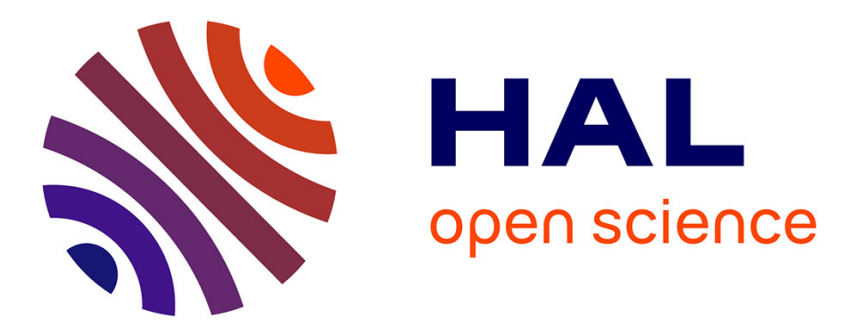

\title{
The implications of seed rain and seed bank patterns for plant succession at the edges of abandoned fields in Mediterranean landscapes
}

\author{
Elise Buisson, Thierry Dutoit, F. Torre, C. Romermann, P. Poschlod
}

\section{- To cite this version:}

Elise Buisson, Thierry Dutoit, F. Torre, C. Romermann, P. Poschlod. The implications of seed rain and seed bank patterns for plant succession at the edges of abandoned fields in Mediterranean landscapes. Agriculture, Ecosystems and Environment, 2006, 115 (1-4), pp.6-14. 10.1016/j.agee.2005.12.003 . hal-01451822

\author{
HAL Id: hal-01451822 \\ https://hal.science/hal-01451822
}

Submitted on 9 May 2018

HAL is a multi-disciplinary open access archive for the deposit and dissemination of scientific research documents, whether they are published or not. The documents may come from teaching and research institutions in France or abroad, or from public or private research centers.
L'archive ouverte pluridisciplinaire HAL, est destinée au dépôt et à la diffusion de documents scientifiques de niveau recherche, publiés ou non, émanant des établissements d'enseignement et de recherche français ou étrangers, des laboratoires publics ou privés. 
The implications of seed rain and seed bank patterns for plant succession at the edges of abandoned fields in Mediterranean landscapes

Elise Buisson $^{\mathrm{a}^{*}}$, Thierry Dutoit ${ }^{\mathrm{b}}$, Franck Torre $^{\mathrm{a}}$, Christine Römermann $^{\mathrm{c}}$, Peter Poschlod $^{\mathrm{c}}$

a Paul Cézanne University, UMR/CNRS 6116 IMEP, FST Saint Jérôme, case 461, 13397 Marseille Cedex 20, France

${ }^{b}$ UMR INRA-UAPV 406 Ecologie des Invertébrés, Université d'Avignon, site Agroparc, Domaine Saint-Paul, 84914, Avignon, France

$10{ }^{c}$ University of Regensburg, Institute of Botany, Universitätsstrasse 31, 93051 Regensburg, 11 Germany

12

13

14

15

* Corresponding author $\quad \mathrm{Ph} .+33.4 .42 .90 .84 .86$

16

e-mail: elise.buisson@univ.u-3mrs.fr

18

19

20

21

22

23 


\section{Abstract}

25 Some environmental variables and above-ground vegetation, seed rain, ant-borne seeds and

26 seed banks were studied on three abandoned fields, at the margins between these fields and a

27 remnant patch of a native steppe vegetation of a high value for nature and species

28 conservation. While the fields were the same size, were adjacent to the same patch of

29 remnant steppe and were cultivated with the same crop, site-specific environmental variables

30 contributed to $23 \%$ of the vegetation patterns; each site was characterised by its unique

31 historical trajectory and thus, by a particular set of species. Distance from boundaries

32 contributed to $10 \%$ of the vegetation patterns. Species characterising the surrounding steppe

33 were found close to boundaries; species characterising abandoned fields were found further

34 away. Winter seed banks and summer deep seed bank did not contribute much to either effect

35 and were characterised by species dating back from past cultivation. Conversely, summer

36 surface seed bank greatly contributed to (83\%) the differences in species composition

37 between the three fields. Seed rain contributed to differences in species composition between

38 fields $(91 \%)$ and distance $(76 \%)$. Ant-borne seeds largely contributed to the differences

39 between fields $(87 \%)$. The colonisation of steppe species on field margins occurs mainly

40 through seed rain and is very slow and incomplete. In a semi-arid fragmented open-

41 landscape, patches of native vegetation do not play a great role in colonisation processes, and itinerant sheep grazing is insufficient to initiate recovery.

Keywords: ants; dry grassland; mosaic of herbaceous communities; seed bank; seed rain; 45 steppe 


\section{Introduction}

While many studies on grazing, mowing and burning regimes have been carried out to plan conservation management for individual grasslands (Hillier et al., 1990; Poschlod and WallisDeVries, 2002), only few studies plan for long-term management within fragmented open-landscapes and studies on secondary succession and edges have yet to be relevant to long-term management. Studies focusing on edges assessed either the influence of agriculture-related factors on field-margin vegetation (Kleijn et al., 1997) or the influence of field-margin vegetation on crops (Dutoit et al., 1999; Von Arx et al., 2002).

Investigating colonisation processes at edges of abandoned fields is important (Wilson and Aebischer, 1995) because the field potential to recover via long-term seed bank or longdistance seed rain has often been found to be relatively low in Northern Europe (Graham and Hutchings, 1988; Hutchings and Booth, 1996a; Kalamees and Zobel, 2002). Studying edges is even more important in dry climates, where drought induces conditions that dramatically slow down successional processes (Blondel and Aronson, 1999). Results may have important conservation implications, particularly in the Mediterranean basin where grasslands harbour a high proportion of endangered taxa (Médail and Quézel, 1999).

The hypothesis of this research was that remnant patches of vegetation are a source of seeds for the colonisation of abandoned fields either by seed rain or ant dispersal. The aims of the present study were (1) to describe the colonisation processes on abandoned field margins over a complete growing season in order to determine how steppe vegetation reestablishes at the margins between abandoned fields and a remnant patch of steppe in order (2) to provide information for the long-term management of abandoned fields.

\section{Methods}

\subsection{Study area}

The study was carried out in the plain of La Crau, located $\sim 50 \mathrm{~km}$ north-west of Marseille in south-eastern France. The steppe vegetation of the plain evolved with: 1) a dry Mediterranean climate; 2$)$ a shallow soil (<400 mm) and an impermeable bedrock; 3 ) itinerant sheep grazing since 3000 BP (Buisson and Dutoit, 2004). The steppe vegetation is dominated by the stress-tolerant species Brachypodium retusum and Thymus vulgaris, which represent $\sim 50 \%$ of the biomass, and is composed of a great diversity of annual species (Buisson and Dutoit, in press). The remnant central patch of steppe was fragmented by row crop and melon cultivations between 1965 and 1985, after which all patches of steppe and fields were grazed by itinerant sheep from February to June.

Three abandoned fields (A, B, C) were selected on the sheepfold of Peau de Meau $\left(43^{\circ} 33^{\prime} \mathrm{E} 4^{\circ} 50^{\prime} \mathrm{N}\right.$, elevation $\left.10 \mathrm{~m}\right)$, in the centre of the plain. All fields were adjacent to one same remnant patch of undisturbed steppe (D) in order to avoid confounding changes in the floristic composition on the margins of abandoned fields with differences due to species composition of steppe patches (Römermann et al., 2005). However, fields had varied cultivation periods, dates of abandonment and locations given in Table 1.

\subsection{Sampling}

On each studied field (A, B, C), three transects $(1,2,3)$ were set out perpendicular to the field boundary. Each transect started at the boundary and stretched towards the centre of abandoned fields and measured $10 \mathrm{~m}$ because the visible gradient of the typical steppe perennial species $T$. vulgaris $\%$ cover never exceeded $10 \mathrm{~m}$. The three transects per field were laid $10 \mathrm{~m}$ apart because most herbaceous species do not disperse by wind over more 
than a few meters (Verkaar et al., 1983), especially in the plain were vegetation grow very low. Collection points were set $1 \mathrm{~m}$ apart along the transects starting at the field edge (point 0 ) between steppe and fields ( 0 to $10 \mathrm{~m} ; 11$ samples). All data were collected in 2001, a year with an average climate.

Above-ground vegetation was recorded in 10 sub-quadrats of $40 \times 40 \mathrm{~cm}$ at each sampling point totalling 990 sub-quadrats, in May 2001. T. vulgaris and B. retusum \% cover, as well as stones, vegetation and bare ground $\%$ cover were visually estimated by one observer in each quadrat. All other species were sampled in each quadrat using the presence/absence method. To avoid disturbing the vegetation, other sampling was taken on the other side of the transects.

$200 \mathrm{~g}$ of soil was taken at sampling points 0,5 and $10 \mathrm{~m}$ along each transect in February 2001 (27 samples total). Samples were dried and sieved through a $200 \mu \mathrm{m}$ mesh sieve. Total nitrogen was measured using the Kjeldahl method, phosphorus using the Olsen method and total carbon using the Anne method (Baize, 2000). The concentrations of calcium, potassium and magnesium available to plants were measured using the Shollenberger and Dreibelbis method (Baize, 2000). The soil $\mathrm{pH}$ was also measured in $\mathrm{H}_{2} \mathrm{O}$ (Baize, 2000).

The persistent seed bank, seeds that persist in the seed bank > 1year, (Thompson et al., 1997) was sampled in February 2001 before the input of fresh seeds and after the germination of most seeds in the fall and winter. To deduce the transient seed bank, the summer seed bank, seeds that persist in the seed bank <1year, (Thompson et al., 1997), was sampled at the beginning of July 2001 after seeds were shed. Cores could not be taken because the soil was extremely rocky. For each sampling point, two $500 \mathrm{~cm}^{3}$ containers were filled, one for the $0-10 \mathrm{~cm}$ depth and one for the $>10 \mathrm{~cm}$ depth $(198$ samples for summer and 198 for winter seed bank). The volume of soil sampled was $1500 \mathrm{~cm}^{3} / \mathrm{soil}$ layer/field/distance from the boundary; the volume recommended by Bakker et al. (1996) was $1200 \mathrm{~cm}^{3}$. The 396 samples of soil seed bank were set to germinate using the standard procedure recommended by Ter Heerdt et al. (1997). Soil samples were washed with water on sieves of $4 \mathrm{~mm}$ and 200 $\mu \mathrm{m}$ mesh sizes to reduce bulk and clay. The concentrated soil was spread in a thin layer in trays filled with $20 \mathrm{~mm}$ of vermiculite and topped with medical compresses of $100 \mu \mathrm{m}$ mesh size. Trays were watered every day from below. Emerged seedlings were identified, counted and removed weekly.

Seed rain was sampled from April $15^{\text {th }}$ to October $15^{\text {th }} 2001$. Sticky traps, made of paper filters coated with grease and placed in $140 \mathrm{~mm}$ diameter Petri dishes (Hutchings and Booth, 1996a), were fixed with pegs at all sampling points along the transects. Sticky papers were changed every two weeks (1287 traps total). Seeds were identified to the species or genus level under a dissecting microscope using a reference collection.

To assess ant seed dispersal from the steppe to the abandoned fields, ant pitfall traps were set out at all sampling points along the transects. These traps, consisting of $50 \mathrm{~mm}$ diameter $\times 100 \mathrm{~mm}$ high containers, were filled with a non-attractive liquid of $50 \%$ glycol to conserve seeds and reduce evaporation, $49 \%$ water, $1 \%$ acetic acid to act as an anti-fungic and a few drops of tensioactive detergent to make the ants sink. Traps were changed every two weeks from April $15^{\text {th }}$ to October $15^{\text {th }} 2001$ (1287 traps total). Seeds were identified to the species or genus level and harvesting ants (Messor barbarus and Messor sanctus) were identified and counted. 


\subsection{Data analyses}

Multivariate analyses were used to study simultaneously the complex relationships among species, and between the species and their environment. A partial canonical correspondence analysis pCCA (Ter Braak, 1987) was used to determine 1) the relationship between the above-ground vegetation and a set of environmental variables once the impact of distance variables was statistically removed; and 2) the relationship above-ground vegetation and the distance from boundaries once the impact of the environmental variables was statistically removed (McIntyre and Lavorel, 1994). The above-ground vegetation data and some environmental variables $\left(\mathrm{pH}, \mathrm{P}_{2} \mathrm{O}_{5}, \mathrm{C}: \mathrm{N}, \mathrm{K}_{2} \mathrm{O}\right.$ and $\%$ cover of vegetation) were used at points 0,5 and $10 \mathrm{~m}$ from boundary.

To identify which of the six data-sets best contributed to the composition of the above-ground vegetation, a K-sets principal component analysis was used (K-sets PCA, Pagès and Escofier,1994). Classical multivariate approaches consider alternatively: i) as many separate PCAs as there are data-sets, but the interpretation is doubtful as it is based on empirical comparisons of separate analyses; ii) a unique overall PCA of all six data-sets, although some may weigh more than others in the analysis. A K-sets PCA allowed us to analyse all six data-sets by weighting differently each variable so that they played a balanced role in the analysis. Separate PCAs were first conducted for each data-set and then the inverse of the first eigenvalue was used as a weighting coefficient for the global K-PCA analysis (Pagès and Escofier, 1994). Computations for the pCCA and the K-sets PCA were performed using ADE4 software (Thioulouse et al., 1997)

To explain plant distribution at field margins, the means per distance ( $\mathrm{n}=9$ transects) were calculated for (1) soil variables (2) total and steppe-only species richness and density of above-ground vegetation, seed rain, seeds in ant-traps, summer and winter surface and deep seed banks. Data were directly compared or $\log _{10}$ transformed (Sokal and Rohlf, 1998) before being compared with one-way ANOVAs (Statistica software, version 6.0), followed by post-hoc tests (Least Significant Difference). Non-parametric multiple comparisons by STP tests (Simultaneous Test Procedure, based on Mann-Whitney U test, Sokal and Rohlf, 1998) were performed on non-normal data.

\section{Results}

The total number of species found in the vegetation, seed bank, seed rain and ant-traps are given for each field in Table 2. All the species found during this study are listed in the Appendix and their frequency of occurrence in each of the various types of data are recorded.

The partial CCA showed that the environmental variables alone explained $23 \%$ of the variance of the above-ground vegetation matrix (no figure). The partial CCA also showed that distances from sampling points to boundary contributed to $10 \%$ of the above-ground vegetation matrix (Fig. 1). This distance effect showed that points close to the boundary were associated with species such as Asphodelus ayardii, B. retusum, Filago pyramidata, Linaria arvensis and $T$. vulgaris, whereas points far from the boundary were associated with species such as Calamintha nepeta, Lepidium graminifolium, Rumex pulcher and Cynoglossum officinale (Fig. 1). Non-parametric multiple comparisons by STP tests confirmed that $T$. vulgaris \% cover was significantly higher at 0,1 and $2 \mathrm{~m}$ from boundaries than at $10 \mathrm{~m}$ $(\mathrm{U}=34.7 p<0.001)$; and phosphorus contents significantly increased with the distance from boundaries $(\mathrm{U}=11.7 p<0.001)$.

Axis 1 of the K-sets PCA was correlated with the first principal components of all seven matrices and particularly with above-ground vegetation (89\%), seed rain (91\%), antborne seed (87\%) and summer surface seed bank (83\%) matrices (Fig. 2), showing 
correlation between these variables. This axis (6\%) separated abandoned field A, associated with species, such as Bromus sp., Diplotaxis tenuifolia, Polycarpon tetraphyllum and Vulpia sp., from abandoned field $\mathrm{C}$ points associated with species, such as Aegilops sp., Bellis sylvestris, Carthamus lanatus and Senecio vulgaris. Abandoned field B points were grouped between A and C. A site effect was thus observable not only on above-ground vegetation but also on most of the types of data studied except on winter seed bank. Axis 2 of the K-sets PCA was particularly correlated with the second components of above-ground vegetation (80\%) and seed rain (76\%) matrices (Fig. 2). This axis (4\%) separated the points close to the boundary from the points far from the boundary. Points close to the boundary were associated with species, such as Erodium cicutarium, Euphorbia exigua, Galium sp. and $P$. tetraphyllum for both matrices as well as Linum trigynum, Sideritis romana and T vulgaris in the vegetation and Brachyposium distachyon and Plantago bellardii in the seed rain (Fig. 3). Points far from the boundary were associated with species, such as Conyza sp. in the vegetation and Lobularia maritima in the seed rain (Fig. 3).

ANOVA showed that steppe species richness of above-ground vegetation and steppe species richness of seed rain were significantly higher at $0,1,2$, and $3 \mathrm{~m}$ as well as $4 \mathrm{~m}$ for vegetation than at 7 to $10 \mathrm{~m}$ from boundaries (respectively $F=9.5$ and $F=6.1, P<0.001$ and LSD test $P<0.05)$.

\section{Discussion}

Independently from the site effect and from the differences in species number found on each field (Table 2) which are well-known phenomena (Buisson and Dutoit, 2004), original patterns were observed which were comparable on the three field margins. The composition of above-ground vegetation changed with distance from boundary: there were more steppe species close to boundaries and more arable weed species and mesophilous species further away. Soil $\mathrm{pH}$ and soil concentrations in phosphorus increased with distance from boundary because more fertiliser was applied on the fields than on the field margins that were less deeply ploughed. Grime et al. (1987) and Gough and Marrs (1990) have shown that ruderal species out-compete dry grassland species when phosphorus is in excess. Although a phosphorus gradient existed on the field margins in this study, Buisson and Dutoit (2004) have shown that concentrations observed in La Crau were not high enough on field margins (mean phosphorus $=0.019 \mathrm{~g} / \mathrm{kg}$ ) to explain the degree of vegetation change (Janssens et al., 1998).

On field margins, the deep seed bank mainly consisted of arable weed species (Kickxia elatine and Portulaca oleracea), ruderal and nitrophilous species (Calamintha nepeta, L. maritima, Polygonum aviculare, S. vulgaris, Solanum nigrum) dating back to melon cultivation. The surface seed bank consisted not only of recently established steppe species (seed bank <1 year), but also of the species cited above, some of which (e.g. $P$. oleracea and S. nigrum) have not been found in above ground vegetation since the abandonment of melon cultivation because favourable conditions no longer exist (ploughing, fertiliser, irrigation etc.). Re-establishment of steppe species from seed bank appeared to be minimal, as most steppe species were shown to have a transient seed bank (see also Römermann et al., 2005), although margins offered better environmental conditions for stress-tolerant steppe species than the middle of the fields.

The stress-tolerant steppe species now growing on field margins, but absent in the seed bank, came from seed rain or ant-borne seeds. Seed dispersal by ants on the margins, while worth noting (about 10000 seeds and 10000 ants trapped throughout the study), was probably limited to small distances, as observed by Harrington and Driver (1995). Seed rain 
thus contributed to most steppe species colonisation. Even sampled over a complete fructification and dispersal season, seed rain and seed dispersal by ants did not suffice for the re-establishment of steppe species on the fields since only a few steppe species were found on margins while typical steppe species such as Stipa capillata, A. ayardii, Plantago holosteum, Hyssopus canescens, and Fumana procumbens were not. These results contrast strongly with Etienne et al.'s (1998) assessment of potential steppe vegetation reestablishment in La Crau and with results found in north-western Europe (Gibson and Brown, 1992).

The results of this study under Mediterranean climate show that the role of the seed bank in the re-establishment of former steppe on abandoned fields is minimal and thus corroborate those found elsewhere (Graham and Hutchings, 1988; Hutchings and Booth, 1996a). While in many landscapes, remnant patches of native vegetation have a positive role on the secondary succession of abandoned fields, in a Mediterranean fragmented openlandscape, remnant patches of steppe adjacent to abandoned fields do not seem to have much of a role in the colonisation processes of steppe species as seed dispersal by wind or ants is limited.

Plant and insect dispersal in fragmented landscape has been studied in open landscapes and it has been concluded that livestock (Poschlod et al., 1998) are an excellent vector to disperse seeds between plots by epizoochory and endozoochory (Fischer et al., 1996) in Northern Europe. The steppe of La Crau and abandoned fields are grazed by itinerant sheep and their daily ranging patterns could easily be planned so that they graze on the steppe first, then on fields, in order to disperse steppe-species seeds and insects onto fields. However, grasshoppers thrive and most plants set seeds in summer (Bourrelly et al., 1983) when all flocks are in transhumance in the Alps. Also, Fischer et al. (1996) have shown that most of the seeds dispersed came from plants bigger than $80 \mathrm{~cm}$ high and Dutoit et al. (2003) have shown that, in a Mediterranean area where sheep graze year around, sheep were not a good vector of rare arable weeds. In La Crau, most dicotyledons grow rather small and have small and smooth seeds resembling those of rare arable weeds. Therefore, although sheep grazing is required to maintain steppe vegetation (Fabre and Pluvinage, 1998), it is not sufficient for the long-term management of abandoned fields.

The long-term conservation of the steppe has to include a plan to re-connect the larger patches of steppe. Future experiments should focus on sowing seeds or transplanting nurse species. This management tool has been used to enhance species richness of grasslands in northern Europe. Its success depends on the seeds sown (Hutchings and Booth, 1996b), on facilitation processes between transplanted nurse species and others native species (Pywell et al., 2002) or on concurrent vegetation management (Warren et al., 2001).

\section{Acknowledgements}

This study was financed with a grant from "Ministère du Développement Durable et de l'Ecologie”, program 'Espaces Protégés'. We acknowledge the CEEP Ecomusée de Crau, $\mathrm{Mr}$ Bernhardt, Fadda, Gerbaud, and Mrs Bottone, Rolando, and Trivelly for technical support and field assistance, as well as Mr Hayes and Mrs Sweetko for proof reading the manuscript. We also thank several anonymous reviewers for helpful comments on the manuscript. 


\section{References}

Baize, D., 2000. Guide des analyses en pédologie. INRA, Paris.

Bakker, J.P., Poschlod, P., Strykstra, R.J., Bekker, R.M., Thompson., K., 1996. Seed banks and seed dispersal: important topics in restoration ecology. Acta Botanica Neerlandica 45, 461-490.

Blondel, J., Aronson, J., 1999. Biology and Wildlife of the Mediterranean Region. Oxford University Press, Oxford.

Bourrelly, M., Borel, L., Devaux, J.P., Louis-Palluel, J., Archiloque, A., 1983. Dynamique annuelle et production primaire nette de l'écosystème steppique de Crau. BiologieEcologie méditerranéenne 10, 55-82.

Buisson, E., Dutoit, T., 2004. Colonisation by native species of abandoned farmland adjacent to a remnant patch of Mediterranean steppe. Plant Ecology 174, 371-384.

Buisson, E., Dutoit, T., in press. Creation of the Natural Reserve of La Crau: implications for the creation and management of protected areas. Journal of Environmental Management.

Dutoit, T., Gerbaud, E., Ourcival, J.M., 1999. Field boundary effects on soil seed banks and weed vegetation distribution in an arable field without weed control (Vaucluse, France). Agronomie, Agriculture and Environnement 19, 579-590.

Dutoit, T., Jäger, M., Gerbaud, E., Poschlod, P., 2003. Rôles des ovins dans le transport de graines d'espèces messicoles: le cas d'une exploitation agricole du Parc Naturel Régional du Luberon. Courrier scientifique du Parc régional du Luberon 7, 68-75.

Etienne, M., Aronson, J., Le Floc'h, E., 1998. Abandoned lands and land use conflicts in southern France. Piloting ecosystem trajectories and redesigning outmoded landscapes in the 21st century. In: Rundel, P.W., Montenegro, G., Jaksic, F. (Eds), Landscape degradation and biodiversity in Mediterranean-type ecosystems. Ecological Studies Series $\mathrm{n}^{\circ} 136$. Springer, Berlin, pp. 127-140.

Fabre, P., Pluvinage, J., 1998. Intégration des mesures agri-environnementales aux systèmes d'élevage ovin de la Crau. In: CEEP Ecomusée de Crau (Eds), Patrimoine nature et pratiques pastorales en Crau. Saint-Martin de Crau, France, pp. 100-113.

Fischer, S.F., Poschlod, P., Beinlich, B., 1996. Experimental studies on the dispersal of plants and animals on sheep in calcareous grasslands. Journal of Applied Ecology 33, 1206-1222.

Gibson, C.W.D., Brown, V.K., 1992. Grazing and vegetation change: deflected or modified succession? Journal of Applied Ecology 29, 120-131.

Gough, M.W., Marrs, R.H., 1990. A comparison of soil fertility between semi-natural and agricultural plant communities: implications for the creation of species-rich grasslands on abandoned agricultural land. Biological Conservation 51, 83- 96.

Graham, D. J., Hutchings, M.J., 1988. A field investigation of germination from the seed bank of a chalk grassland ley established on former arable land. Journal of Applied Ecology 25, 253-263.

Grime, J.P., MacKey, J.M.L, Hillier, S.H., Read, D.J., 1987. Floristic diversity in a model system using experimental microcosms. Nature 328, 420-422.

Harrington, G.N., Driver, M.A., 1995. The effect of fire and ants on the seed-bank of a shrub in a semi-arid grassland. Australian Journal of Ecology 20, 238-247.

Hillier, S.H., Walton, D.W.H., Wells, D.A., 1990. Calcareous grassland: ecology and management. Bluntisham Books, Bluntisham. 
Hutchings, M.J., Booth, K.D., 1996a. Studies on the feasibility of re-creating chalk grassland vegetation on ex-arable land. I. The potential roles of the seed bank and the seed rain. Journal of Applied Ecology 33, 1171-1181.

Hutchings, M.J., Booth, K.D., 1996b. Studies on the feasibility of re-creating chalk grassland vegetation on ex-arable land. II. Germination and early survivorship of seedlings under different management regimes. Journal of Applied Ecology 33, 1182-1190.

Janssens, F., Peeters, A., Tallowin, J.R.B., Bakker, J.P., Bekker, R.M., Fillat, F., Oomes, M.J.M., 1998. Relationship between soil chemical factors and grassland diversity. Plant and Soil 202, 69-78.

Kalamees, R., Zobel, M., 2002. The role of the seed bank in gap regeneration in a calcareous grassland community. Ecology 83, 1017-1025.

Kerguélen, M., 1999. Index synonymique de la flore de France. [pages html]. INRA Dijon. http://www.dijon.inra.fr/flore-france/ [October 1999 ; last checked in September 2005].

Kleijn, D., Joenje, W., Kropff, M.J., 1997. Patterns in species composition of arable field boundary vegetation. Acta Bot. Neerl. 46, 175-192.

McIntyre, S., Lavorel, S., 1994. How environmental and disturbance factors influence species composition in temperate Australian grasslands. Journal of Vegetation Science $8,521-531$.

Médail, F., Quézel, P., 1999. Biodiversity hotspots in the Mediterranean Basin: setting global conservation priorities. Conservation Biology, 13, 1510-1513.

Pagès, J., Escofier, B., 1994. Multiple factor analysis (AFMULT package). Computational Statistics and Data Analysis 18, 121-140.

Poschlod, P., Kiefer, S., Tränkle, U., Fisher, S., Bonn, S., 1998. Plant species richness in calcareous grasslands as affected by dispersability in space and time. Applied Vegetation Science 1, 75-90.

Poschlod, P., WallisDeVries, M.F., 2002. The historical and socio-economic perspective of calcareous grasslands-lessons from the distant and recent past. Biological Conservation 104, 361- 376.

Pywell, R. F., Bullock, J.M., Hopkins, A., Walker, K.J., Sparks, T.H., Burke, M.J.W., Peel, S., 2002. Restoration of species-rich grassland on arable land: assessing the limiting processes using a multi-site experiment. Journal of Applied of Ecology 39, 294-309.

Römermann, C., Dutoit, T., Poschlod, P., Buisson, E., 2005. Influence of former cultivation on the unique Mediterranean steppe of France and consequences for conservation management. Biological Conservation 121, 21-33

Sokal, R. R., Rohlf, F.J., 1998. Biometry: the principles and practice of statistics in biological research. 3rd edition, W. H. Freeman Company, New York.

Ter Braak, C.J.F., 1987. The analysis of vegetation-environment relationships by canonical correspondence analysis. Vegetatio 69, 69-77.

Ter Heerdt, G.N.J., Verweij, G.L., Bekker, R.M., Bakker, J.P., 1997. An improved method for seed-bank analysis: seedling emergence after removing the soil by sieving. Functional Ecology 10, 144-151.

Thioulouse, J., Chessel, D., Dolédec, S., Olivier, J.M., 1997. ADE-4: a multivariate analysis and graphical display software. Statistics and Computing 7, 75-83.

Thompson, K., J. Bakker, and R. Bekker. 1997. The soil seed bank of North West Europe: methodology, density and longevity. Cambridge University Press, Cambridge.

Verkaar, H.J., Schenkeveld, A.J., Van De Klashorst, M.P., 1983. On the ecology of short lived forbs in chalk grasslands: dispersal of seeds. New Phytologist 95, 335-344. 
375

376

377

378

379

380

381

382

383
Von Arx, G., Bosshard, A., Dietz, H., 2002. Land-use intensity and border structures as determinants of vegetation diversity in an agricultural area. Bulletin of the Geobotanical Institute ETH 68, 3-15.

Warren, J., Christal, A., Wilson, F., 2001. Effects of sowing and management on vegetation succession during grassland habitat restoration. Agriculture, Ecosystems and Environment 1909, 1-10.

Wilson, P.J., Aebischer, N.J., 1995. The distribution of dicotyledonous arable weeds in relation to distance from the field edge. Journal of Applied Ecology 32, 295-310. 

quadrats of $40 \times 40 \mathrm{~cm}$ ), in the 1287 seed rain traps, in the 1287 ant traps and in the various

\begin{tabular}{|c|c|c|c|c|c|c|c|c|}
\hline Species & 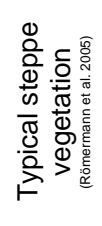 & 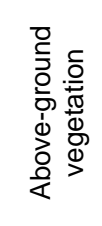 & 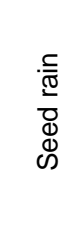 & $\begin{array}{l}0 \\
0 \\
0 \\
0 \\
0 \\
\dot{0} \\
\frac{1}{2} \\
8 \\
\frac{0}{1} \\
\frac{1}{4}\end{array}$ & 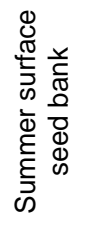 & 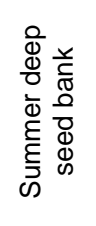 & 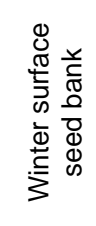 & 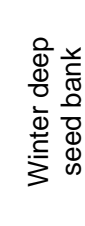 \\
\hline Aegilops ovata $\mathrm{L}$. & $\mathrm{X}$ & 98.4 & 0.9 & 0.3 & 0.4 & & & \\
\hline Aira cupaniana Guss. & $\mathrm{X}$ & 98.2 & 0.1 & 0.4 & 1.3 & & & \\
\hline Anagallis arvensis $\mathrm{L}$. & & 32.1 & & & 5.2 & 30.6 & 12.0 & 20.1 \\
\hline Anagallis foemina Miller & & 50 & & & 3.8 & & 36.2 & 10.0 \\
\hline Anagallis sp. & & & & 100.0 & & & & \\
\hline Asperula cynanchica L. & $\mathrm{X}$ & 100.0 & & & & & & \\
\hline Asphodelus ayardii L. & $\mathrm{X}$ & 100.0 & & & & & & \\
\hline Asterolinon linum-stellatum (L.) Duby in DC. & $\mathrm{X}$ & 96.6 & 3.0 & 0.4 & & & & \\
\hline Avena barbata Link & $\mathrm{X}$ & 98.8 & 0.7 & 0.4 & 0.1 & $<0.05$ & & \\
\hline Bellis sylvestris Cirillo & $\mathrm{X}$ & 99.3 & 0.5 & 0.2 & & & & \\
\hline Brachypodium distachyon (L.) P. Beauv. & $\mathrm{X}$ & 37.7 & 9.4 & 2.5 & 50.0 & 0.4 & & \\
\hline Brachypodium retusum (Pers.) P. Beauv. & $\mathrm{X}$ & 100.0 & & & & & & \\
\hline Bromus hordeaceus L. subsp. hordeaceus & & 87.8 & 2.0 & 0.5 & 9.5 & 0.2 & & \\
\hline Bromus intermedius Guss. & & 85.1 & 8.8 & 1.4 & 4.3 & 0.4 & & \\
\hline Bromus madritensis $\mathrm{L}$. & & 84.6 & 1.4 & 8.1 & 5.9 & & & \\
\hline Bromus rubens L. & & 78.7 & 6.6 & 0.6 & 14.0 & 0.1 & & \\
\hline Bromus sp. & & & & & & & 50.00 & 50.00 \\
\hline Calamintha nepeta (L.) Savi & & 91.4 & & $<0.05$ & 5.2 & 0.7 & 2.1 & 0.4 \\
\hline Carduus nigrescens Vill. & & 58.6 & 9.9 & 25.7 & 5.8 & & & \\
\hline Carduus tenuiflorus Curtis & & 99.7 & 0.18 & 0.02 & 0.1 & & & \\
\hline Carex sp. & & & & & & & & 100.0 \\
\hline Carlina corymbosa L. & $\mathrm{X}$ & 100.0 & & & & & & \\
\hline Carlina lanata $\mathrm{L}$. & $\mathrm{X}$ & 99.8 & 0.1 & 0.1 & & & & \\
\hline Carthamus lanatus L. & $\mathrm{X}$ & 99.99 & 0.01 & & & & & \\
\hline $\begin{array}{l}\text { Catapodium rigidum (L.) C.E. Hubbard in } \\
\text { Dony }\end{array}$ & $\mathrm{X}$ & 90.1 & 0.9 & 0.2 & 8.8 & $<0.05$ & & \\
\hline Cerastium glomeratum Thuill. & $\mathrm{x}$ & 98.6 & & & 1.4 & & & \\
\hline Cerastium sp. & & & & 13.6 & & & 86.40 & 0.00 \\
\hline Chenopodium album $\mathrm{L}$. & & & & & 11.4 & 22.7 & 20.45 & 45.45 \\
\hline Convolvulus cantabrica L. & & 100.0 & & & & & & \\
\hline Conyza sp. & & 54.4 & 0.2 & 0.6 & 26.5 & 5.5 & 10.53 & 2.27 \\
\hline Crepis foetida L. & $\mathrm{X}$ & 100.0 & & & & & & \\
\hline Crepis sancta (L.) Bornm. & $\mathrm{x}$ & 100.0 & & & & & & \\
\hline Crepis sp. & & & 29.3 & 31.3 & 26.3 & 13.1 & & \\
\hline Cynoglossum officinale L. & & 92.6 & 7.4 & & & & & \\
\hline Dactylis glomerata L. & $\mathrm{X}$ & 90.4 & 5.06 & 0.3 & 3.8 & 0.4 & $<0.05$ & 0.01 \\
\hline Daucus carota L. & $\mathrm{X}$ & 100.0 & & & & & & \\
\hline Diplotaxis tenuifolia (L.) DC. & & 98.4 & 0.1 & & 0.4 & 0.2 & 0.7 & 0.2 \\
\hline Erodium cicutarium (L.) L'Hérit. in Aiton & & 99.0 & 0.4 & 0.3 & 0.3 & & & \\
\hline Eryngium campestre L. & $\mathrm{X}$ & 99.8 & 0.1 & 0.1 & $<0.05$ & & & \\
\hline Euphorbia cyparissias L. & $\mathrm{X}$ & 99.8 & 0.1 & 0.1 & & & & \\
\hline $\begin{array}{l}\text { Euphorbia exigua L. } \\
\text { Euphorbia sequieriana Necker }\end{array}$ & $\mathrm{x}$ & $\begin{array}{c}98.8 \\
100.0\end{array}$ & 0.8 & 0.3 & 0.1 & $<0.05$ & & \\
\hline Evax pygmaea (L.) Brot. & $x$ & 99.8 & & 0.2 & & & & \\
\hline Filago pyramidata L. & $X$ & 99.7 & & & & & 0.15 & 0.15 \\
\hline Filago sp. & & & 98.9 & 1.1 & & & & \\
\hline Galactites elegans (All.) Soldano & & 98.3 & 0.1 & 1.3 & 0.3 & & & \\
\hline Galium murale (L.) All. & $\mathrm{X}$ & 99.3 & 0.2 & & 0.5 & & & \\
\hline Galium parisiense L. / G. pumilum Murray & $\mathrm{X}$ & 97.3 & 1.7 & 0.4 & 0.4 & 0.1 & 0.1 & $<0.05$ \\
\hline Gastridium ventricosum (Gouan) Schinz \& Thell. & $\mathrm{X}$ & 93.8 & 3.5 & 0.4 & 2.3 & & & \\
\hline Geranium molle L. & $\mathrm{x}$ & 95.1 & 1.3 & 0.5 & 3.0 & 0.1 & & \\
\hline Hedypnois cretica (L.) Dum.-Cours. & & 98.23 & 0.01 & 0.23 & 1.4 & $<0.05$ & & $<0.05$ \\
\hline Hordeum murinum L. & & 96.1 & 1.9 & 0.3 & 1.7 & $<0.05$ & & \\
\hline Hypochaeris glabra L. & $X$ & 97.1 & 1.9 & 0.6 & 0.4 & & & \\
\hline Juncus bufonius L. & & & & & & & 50.0 & 50.0 \\
\hline
\end{tabular}




\begin{tabular}{|c|c|c|c|c|c|c|c|c|}
\hline Juncus subnodulosus Schrank & & & & & & & 50.0 & 50.0 \\
\hline Kickxia elatine (L.) Dumort. & & & & & 14.3 & 48.2 & 23.2 & 14.3 \\
\hline Lepidium graminifolium L. & & 97.9 & 0.2 & 0.1 & & & 1.6 & 0.2 \\
\hline Linaria arvensis (L.) Desf. & $\mathrm{X}$ & 99.9 & 0.1 & & & & & \\
\hline Linum strictum $\mathrm{L}$. & $x$ & 98.5 & 1.3 & 0.2 & & & & \\
\hline Linum trigynum $\mathrm{L}$. & & 100.0 & & & & & & \\
\hline Lobularia maritima (L.) Desv. & & 91.1 & 0.3 & 0.2 & 5.5 & 0.5 & 1.6 & 0.8 \\
\hline Logfia gallica (L.) Cosson \& Germain & $\mathrm{X}$ & 97.0 & 1.7 & 0.1 & 0.9 & & 0.2 & 0.1 \\
\hline Lolium perenne L. & & 100.0 & & & & & & \\
\hline Lolium rigidum Gaudin & & 100.0 & & & & & & \\
\hline Lolium sp. & & & 22.5 & 2.3 & 75.0 & 0.2 & & \\
\hline Marrubium vulgare $\mathrm{L}$. & & 100.0 & & & & & & \\
\hline Medicago minima (L.) L. & $x$ & 99.7 & 0.3 & & & & & \\
\hline Medicago praecox DC. & & 100.0 & & & & & & \\
\hline Medicago rigidula (L.) All. & & 99.8 & 0.2 & & & & & \\
\hline Melica ciliata $\mathrm{L}$. & & 37.1 & 36.0 & 24.1 & 1.9 & 0.9 & & \\
\hline Neatostema apulum (L.) I.M. Johnston & & 100.0 & & & & & & \\
\hline Onopordum illyricum $\mathrm{L}$. & & 98.1 & & 1.9 & & & & \\
\hline Panicum capillare L. & $\mathrm{X}$ & & & & & & 100.0 & \\
\hline Petrorhagia prolifera (L.) P.W. Ball \& Heywood & & 99.6 & 0.3 & 0.1 & & & & \\
\hline Phleum pratense $\mathrm{L}$. & & 87.3 & 1.1 & 3.7 & 7.9 & & & \\
\hline Plantago bellardii All. & $X$ & 72.5 & 27.2 & 0.3 & & & & \\
\hline Plantago lagopus $\mathrm{L}$. & & 92.8 & 0.2 & & 5.8 & 1.2 & & \\
\hline Poa annua L. & & & & 34.8 & 40.6 & 4.9 & 14.8 & 4.9 \\
\hline Polycarpon tetraphyllum (L.) L. & & 95.0 & 2.8 & 0.4 & 0.2 & $<0.05$ & 1.3 & 0.3 \\
\hline Polygonum aviculare L. & & & & & 69.2 & 23.1 & 7.7 & \\
\hline Portulaca oleracea L. & & & & & 6.8 & 44.1 & 19.6 & 29.5 \\
\hline Potentilla sp. & & & & & 100.0 & & & \\
\hline Psilurus incurvus (Gouan) Schinz \& Thell. & & & 54.9 & 25.5 & 18.7 & 0.9 & & \\
\hline Ranunculus paludosus Poiret & & & & & 100.0 & & & \\
\hline Reichardia picroides (L.) Roth & $\mathrm{X}$ & 100.0 & & & & & & \\
\hline Reseda sp. & & 100.0 & & & & & & \\
\hline Rostraria cristata (L.) Tzvelev & $\mathrm{X}$ & 92.8 & 2.8 & 1.1 & 3.0 & 0.3 & & \\
\hline Rumex pulcher L. & & 99.9 & 0.1 & & & & & \\
\hline Sagina apetala Ard. & $\mathrm{X}$ & 83.3 & & & 16.7 & & & \\
\hline Salvia verbenaca $\mathrm{L}$. & $\mathrm{X}$ & 99.8 & & $<0.05$ & 0.2 & & $<0.05$ & \\
\hline Samolus valerandi $\mathrm{L}$. & & & & & & & 100.0 & \\
\hline Sanguisorba minor Scop. & $X$ & 99.8 & & & 0.2 & & & \\
\hline Scirpus sp. & & & & & & & 39.9 & 60.1 \\
\hline Senecio vulgaris $\mathrm{L}$. & & 13.1 & & & 75.0 & 2.2 & 8.4 & 1.3 \\
\hline Sherardia arvensis $\mathrm{L}$. & $x$ & 99.98 & & 0.02 & & & & \\
\hline Sideritis romana L. & $X$ & 98.0 & $<0.05$ & 0.2 & 1.6 & 0.2 & & \\
\hline Silene gallica L. & $X$ & 95.4 & 4.6 & & & & & \\
\hline Solanum nigrum L. & & & & 0.6 & 8.1 & 14.2 & 24.4 & 52.7 \\
\hline Sonchus asper (L.) Hill & & 95.4 & 1.4 & 0.2 & 3.0 & & & \\
\hline Stipa capillata L. & $x$ & & & & 100.0 & & & \\
\hline Taeniatherum caput-medusae (L.) Nevski & $\mathrm{x}$ & 99.0 & 0.3 & 0.5 & 0.2 & & & \\
\hline $\begin{array}{l}\text { Thymus vulgaris } \mathrm{L} \text {. } \\
\text { Torilis nodosa (L.) Gaertner }\end{array}$ & $x$ & 93.0 & 1.1 & 0.5 & 4.6 & 0.3 & 0.4 & 0.1 \\
\hline $\begin{array}{l}\text { Torilis nodosa (L.) Gaertner } \\
\text { Trifolium campestre Schreber in Sturm }\end{array}$ & $X$ & $\begin{array}{l}100.0 \\
95.5\end{array}$ & & 0.2 & 4.3 & & & \\
\hline Trifolium glomeratum $\mathrm{L}$. & $\mathrm{X}$ & 95.8 & 0.02 & 0.2 & 2.5 & 0.48 & 0.3 & 0.7 \\
\hline Trifolium scabrum L. & & 99.48 & $<0.05$ & 0.08 & 0.2 & 0.1 & & 0.1 \\
\hline Trifolium sp. & & 97.8 & 0.2 & & 1.6 & 0.40 & & \\
\hline Trifolium stellatum L. & $\mathrm{X}$ & 98.6 & 0.1 & 0.6 & 0.7 & & & \\
\hline Trifolium subterraneum L. & & 100.0 & & & & & & \\
\hline Trifolium suffocatum $\mathrm{L}$. & & 93.3 & 0.2 & 1.5 & 4.6 & 0.3 & & 0.1 \\
\hline Trigonella monspeliaca L. & $\mathrm{X}$ & 97.1 & 0.1 & 0.4 & 2.2 & 0.2 & & \\
\hline Typha latifolia L. & & & & & & & 72.2 & 27.8 \\
\hline Verbascum sinuatum L. & & 100.0 & & & & & & \\
\hline Verbena officinalis L. & & & & & 12.8 & 18.0 & 43.6 & 25.6 \\
\hline Veronica arvensis L. & & 96.1 & 0.2 & $<0.05$ & 3.3 & $<0.05$ & 0.3 & $<0.05$ \\
\hline Vulpia sp. & & 61.4 & 6.3 & 1.3 & 30.3 & 0.7 & $<0.05$ & \\
\hline
\end{tabular}


392 Table 1. Cultivation history of the three abandoned fields A, B, C and the steppe on the 393 sheepfold of Peau de Meau. After abandonment, grazing occurred on all fields, as on the 394 steppe, by itinerant sheep from February to June.

\begin{tabular}{|c|c|c|c|}
\hline Sites & Type of cultivation & $\begin{array}{l}\text { Duration of cultivation } \\
\& \text { year of abandonment }\end{array}$ & Field location \\
\hline Field A & Melons (small tunnels) & 1 year in 1971 & N-NW of the steppe \\
\hline 5 ha & Cereals and alfalfa & 1 year in 1972 & patch (D) \\
\hline Field B & Cereals and alfalfa & from 1960 to 1966 & $\mathrm{~W}$ of the steppe patch \\
\hline \multirow[t]{2}{*}{5 ha } & Melons (small tunnels) & 1 year in 1971 & (D) \\
\hline & Cereals and alfalfa & 1 year in 1972 & \\
\hline Field C & Melons (small tunnels) & 1 year in 1968 & W-SW of the steppe \\
\hline \multirow[t]{2}{*}{5 ha } & Cereals and alfalfa & 1 year in 1969 & patch (D) \\
\hline & $\begin{array}{l}\text { Melons, courgettes, aubergines, } \\
\text { peppers (large tunnels) }\end{array}$ & from 1979 to 1984 & \\
\hline $\begin{array}{l}\text { Steppe D } \\
6500 \text { ha }\end{array}$ & Not cultivated & na & na \\
\hline
\end{tabular}


399 Table 2. Species and germination or seed number of abandoned field A, B and C in the 400 vegetation, soil seed bank, seed rain and ant-borne seeds.

401

402

\begin{tabular}{|c|c|c|c|c|}
\hline & A & $\mathrm{B}$ & $\mathrm{C}$ & Total \\
\hline \multicolumn{5}{|l|}{ Vegetation (33 sampling points / field) } \\
\hline Species number in the vegetation & 63 & 66 & 83 & 94 \\
\hline \multicolumn{5}{|l|}{ Soil seed bank (198 soil samples / season) } \\
\hline Species number in summer seed bank & 58 & 54 & 58 & 73 \\
\hline Seedling number in summer seed bank & 7562 & 7292 & 4684 & 19538 \\
\hline Species number in winter seed bank & 27 & 28 & 21 & 39 \\
\hline Seedling number in winter seed bank & 691 & 375 & 497 & 1563 \\
\hline \multicolumn{5}{|l|}{ Seed rain (1287 traps) } \\
\hline Number of taxa & 52 & 62 & 65 & 76 \\
\hline Seed number & 20880 & 13802 & 8019 & 42701 \\
\hline \multicolumn{5}{|l|}{ Ant-borne seeds (1287 traps) } \\
\hline Number of taxa & 46 & 49 & 61 & 69 \\
\hline Seed number & 4402 & 3140 & 2414 & 10588 \\
\hline
\end{tabular}

403

404 


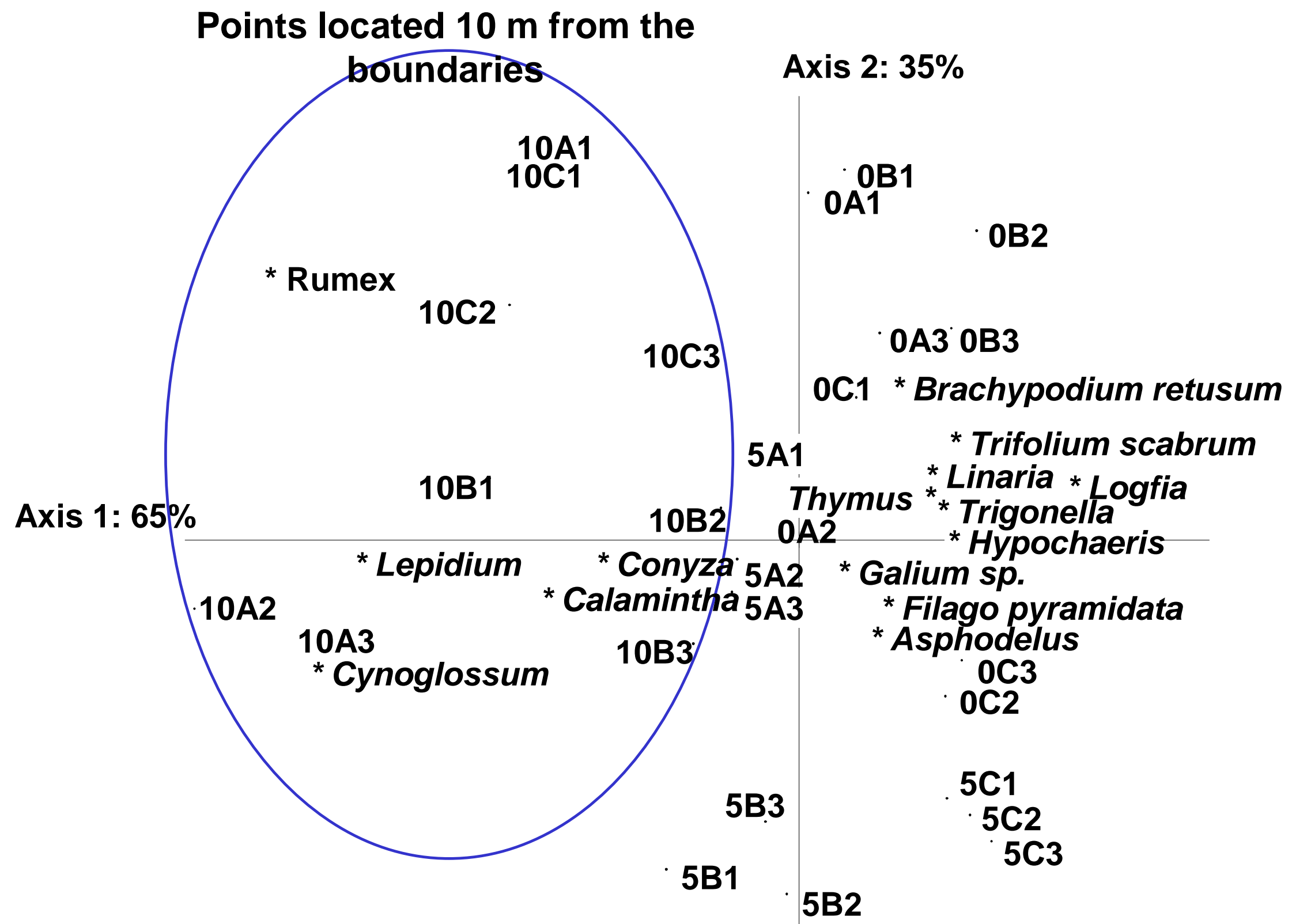

Fig. 1. Partial CCA performed on distance and vegetation variables once the impact of environmental variables was statistically removed. All sampling points are shown. Point abbreviations: first number $=$ distance to boundary $(0$ to $10 \mathrm{~m})$; letter $=$ field $\mathrm{A}, \mathrm{B}$ or $\mathrm{C}$; second number $=$ transect number $(1,2$ or 3$)$. Only the species with high contributions are shown. The nine sampling points far from the boundaries are circled. 


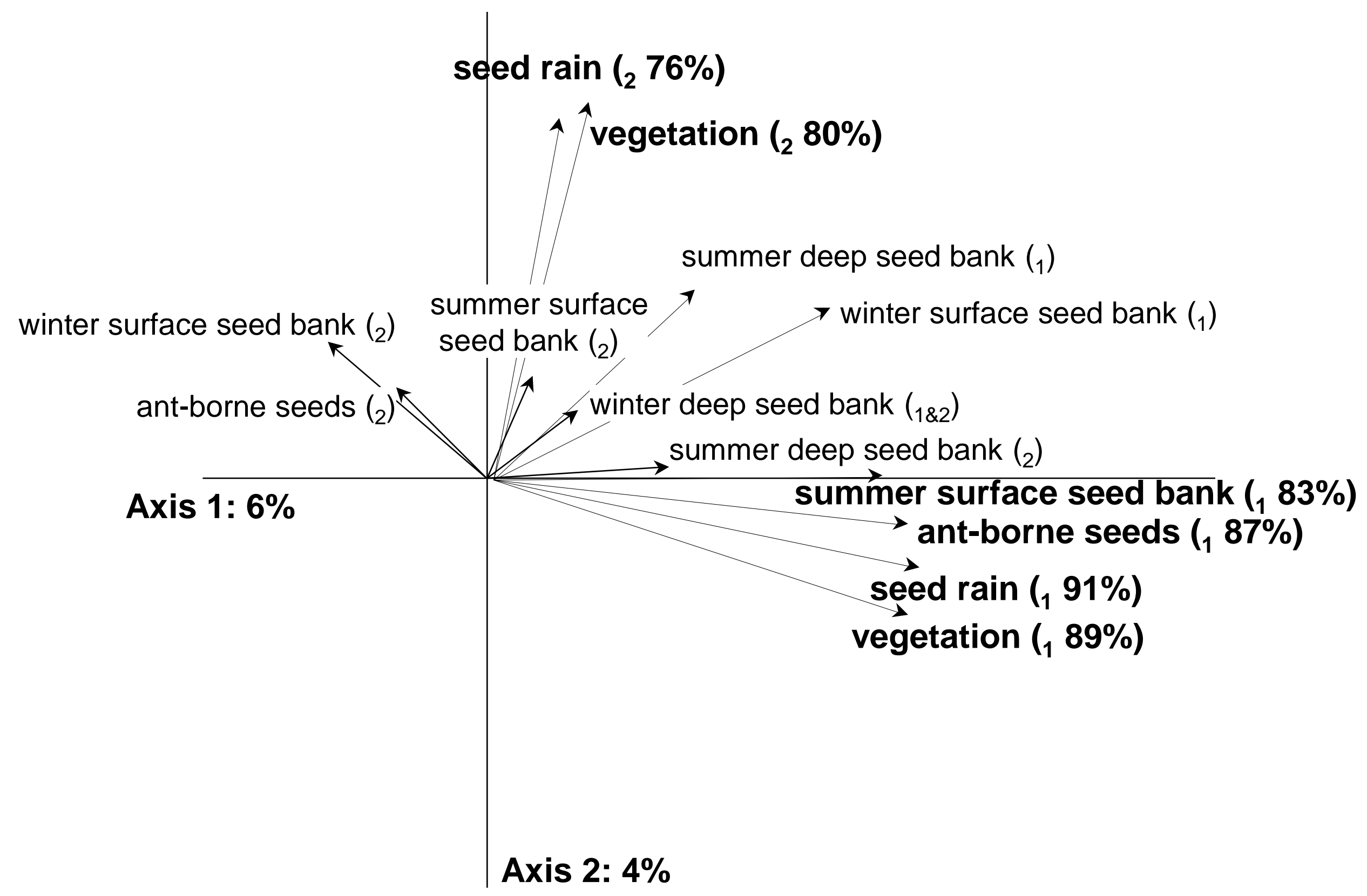




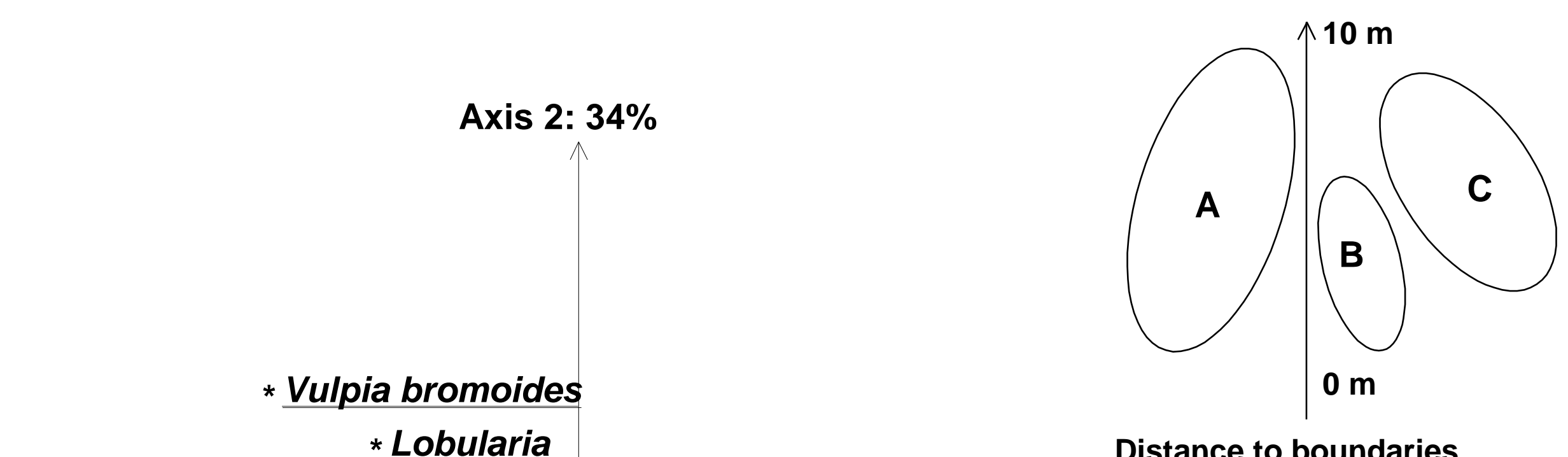

* Bromus rubens $\quad$ Aegilops

Melica

*Bromus hordeaceus

${ }^{\text {* Rostraria }}$

*Asterolinon * Catapodium

Distance to boundaries

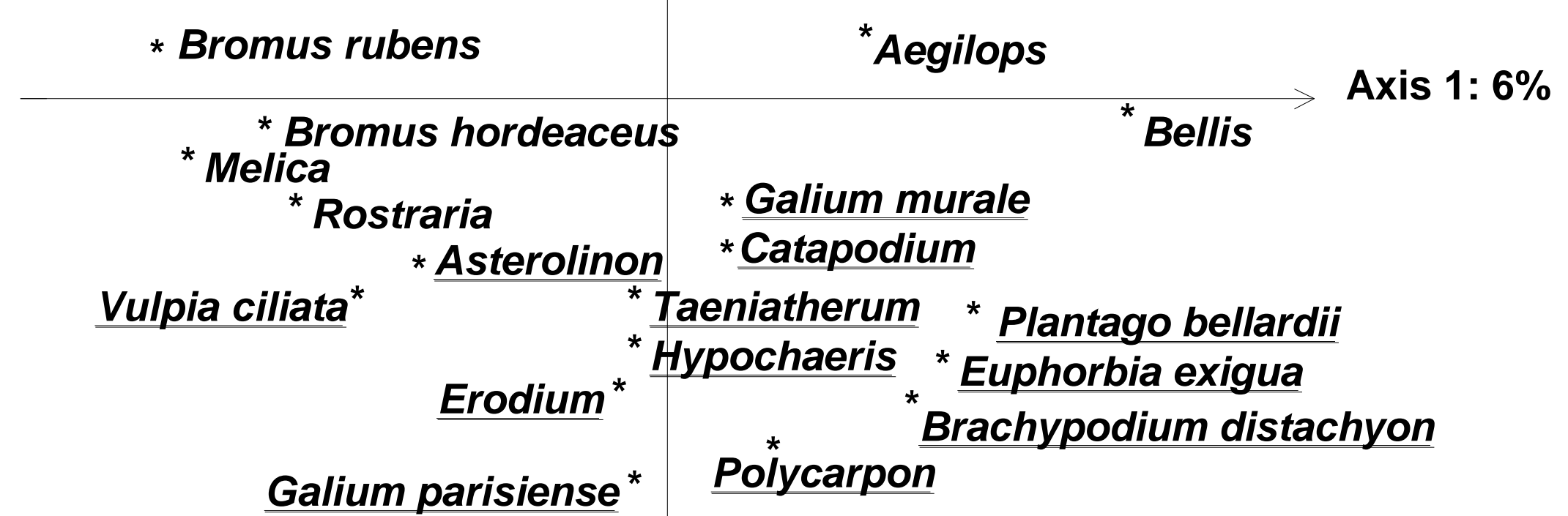

Fig. 3. Factor map of species in the seed rain only, resulting from the K-set PCA. Only species with the highest contributions to axes 1 or 2 are written. Underlined species contribute to axis 2 . The K-set PCA map of sampling points is schematized on the top right corner. 